\title{
Private landowners and environmental conservation: a case study of social- psychological determinants of conservation program participation in Ontario
}

\author{
$\underline{\text { Michael Drescher }}^{1,2}, \underline{\text { G. Keith Warriner }}^{3}, \underline{\text { James R. Farmer }}^{2,4}$ and Brendon M. H. Larson $^{5}$
}

\begin{abstract}
Preservation of biodiversity and continued provision of ecosystem services increasingly relies on environmental conservation on private lands. Despite a multitude of past studies, our knowledge of the motives, opportunities, and challenges of private land conservation, especially on nonworking lands, where financial incentives are less relevant, remains incomplete. A key reason is that a variety of theoretical approaches, resulting in diverging study results, have been used to investigate private land conservation. To help remedy this problem, the current study rigorously examined several established social-psychological determinants of proenvironmental behaviors and developed a comprehensive model, which merged elements from previous studies, to investigate landowner participation in a government-sponsored private land conservation program for nonworking lands. The results are based on analysis of a mailed survey of 800 program-eligible landowners. Contrasting program participants with nonparticipants, we elicited information such as about values, worldviews, socio-demographic characteristics, and property attributes that led landowners to participate in this conservation program. The results of our study illustrate the complex relationships among values, worldviews, norms, attitudes, and behaviors emphasizing the importance of proenvironmental worldviews and of formal education for increasing the likelihood of enrollment in this government-sponsored private land conservation program. Against expectation, neither personal norms, household income, political leaning, nor the size of the eligible property area were found to be important in directly determining the decision to enroll in this conservation program. However, an association of political leaning with stated personal obligation for private land conservation was found. Our results highlight the relationship between formal education and achievement of private land conservation goals through governmental programs for nonworking lands; they also suggest opportunities for supporting conservationminded landowners who are disinclined to engage in governmental programs. To our knowledge, the current study is the first to use a comprehensive model to systematically compare alternative concepts from social psychology such as values, worldviews, norms, and attitudes and their relationships with private land conservation.
\end{abstract}

Key Words: education; environmental conservation; landowner; private land conservation; proenvironmental behavior; social psychology; worldview

\section{INTRODUCTION}

Environmental conservation is essential for the preservation of biodiversity and the continuing provision of ecosystem services (Hooper et al. 2005). This realization has motivated governments to prioritize efforts and develop programs geared toward environmental conservation. For example, the need for biodiversity protection and better stewardship of vital ecosystem services has led to the enactment of rules and regulations for biodiversity conservation from regional to international levels, e. g., Ontario (Government of Ontario 2007), Canada (Government of Canada 2002), and global (UNEP 2010), and an increase in the number and extent of protected areas (2010 Biodiversity Indicators Partnership 2010). However, regulatory policies are both financially and politically costly (Dietz and Stern 2002), and for legal and practical reasons mainly enforceable on public lands.

Preserving biodiversity and conserving ecosystem services on private lands are increasingly recognized as a major requirement for successful environmental conservation at the landscape level (Norton 2000). However, the reach of environmental regulation on private lands is often limited and at times even counterproductive (Brook et al. 2003). Governments have recognized the limited effects of traditional regulatory policies for private land conservation (PLC) and increasingly employ extension activities, technical assistance, as well as incentive and award programs to engender voluntary behaviors in the pursuit of environmental conservation goals (Dietz and Stern 2002, Kauneckis and York 2009). However, it remains a challenge for conservation planning to achieve voluntary environmental protection on private land, especially when focusing on nonworking lands (Hoffman et al. 2002).

The socio-psychological determinants of proenvironmental behavior have been researched since the beginning of modern environmentalism in the 1960s (Stapp et al. 1969). Studies have investigated the socio-demographic correlates of environmentalism (Shen and Saijo 2008) as well as the links between proenvironmental values, beliefs, and attitudes and behaviors across myriad ecological contexts (Winter et al. 2007, Ernst and Wallace 2008, Farmer et al. 2007, Drescher 2014). They also compared alternative economic, political, and social factors that may influence proenvironmental behavior (Nawrotzki 2012). In social psychology a number of models have been proposed, which have investigated the processes by which proenvironmental behavioral intent and outcomes occur. These models, including the theory of reasoned action (Fishbein and Ajzen 1975, Ajzen

${ }^{1}$ School of Planning, University of Waterloo, Waterloo, Ontario, Canada, ${ }^{2}$ Vincent and Elinor Ostrom Workshop in Political Theory and Policy Analysis, Indiana University, Bloomington, Indiana, United States, ${ }^{3}$ Department of Sociology and Legal Studies, University of Waterloo, Waterloo, Ontario, Canada, ${ }^{4}$ Department of Recreation, Park, and Tourism Studies, School of Public Health, Indiana University, Bloomington, Indiana, United States, ${ }^{5}$ School of Environment, Resources and Sustainability, University of Waterloo, Waterloo, Ontario, Canada 
and Fishbein 1980), theory of planned behavior (Ajzen 1985, 1991), norm activation model (Schwartz 1973, 1977), rationale choice theory (Liebe and Preisendörfer 2010), and value-beliefnorm theory (Stern et al. 1999), have proven helpful for predicting positive environmental outcomes by individuals, such as proenvironmental citizenship behavior (e.g., Hungerford and Volk 1990, Kaiser et al. 2005). Additional research has attempted to quantify various socio-political and psychological states, or worldviews, held by individuals in relation to their predisposition to environmentalism (Nooney et al. 2003). However, the diversity of these theoretical approaches has limited the ability to draw general conclusions. The transferability of these earlier studies and models to PLC is not well understood (Larson et al. 2015). Many studies in the social-psychological literature have focused on universal, not place-specific, proenvironmental behaviors such as recycling, water conservation, or environmentally conscious purchasing (Larson et al. 2015). Although there is a rich literature in fields such as forest and rangeland management and conservation (Kamala et al. 2015a), place-specific proenvironmental behaviors that involve physical interactions with a concrete environment, such as PLC, have received much less attention in the social-psychological literature (Larson et al. 2015). Maybe more so than other forms of proenvironmental behaviors, PLC is also tightly linked to, and complicated by, notions of civil liberties such as private property rights and political culture (Jackson-Smith et al. 2005). Consequently, one of the novel contributions of the current study is its systematic comparison and merging of elements of various social-psychological concepts/theories, in the context of PLC.

The goal of this research was to investigate elements of several social-psychological theories and private landowner characteristics that relate to the decision to engage in PLC. In the context of this research, we were interested in private rural landowners, i.e., excluding governmental, nongovernmental, and commercial organizations that hold land. Private rural landowners holding land for any purpose were included, whether it be for income from working lands, purely residential, as investment, or any other reason. PLC in this study is indicated through participation in a government-sponsored PLC program that aims to protect natural heritage features from degradation by activities such as farming, timber harvesting, land development, or other site alterations. Accordingly, nonworking lands are the focus of this study, though these can also be nonworking portions of landholdings that otherwise consist of working land. In the pursuit of our research goal, we employed elements of several social-psychological theories of proenvironmental behavior and merged them into one comprehensive model. Although we considered the influence of financial rewards, we were more interested in the socialpsychological grounds leading to proenvironmental behaviors. To distinguish social-psychological states and worldviews that lead to PLC, we compared private landowners who engaged in PLC to those who did not, while assessing the relative influence of landowner characteristics and alternative theoretical approaches. Our investigation was guided by two research questions: (1) Which elements of various social-psychological theories, e.g., basic values, worldviews, norms, and attitudes, are affecting most the decision to engage in PLC? (2) How is the decision to engage in PLC affected by socio-demographic variables?

\section{CONCEPTUAL FRAMEWORK}

Many studies have investigated the influence of various socialpsychological models on proenvironmental intentions and behaviors. Often these have relied on a single theoretical approach (e.g., Van Liere and Dunlap 1978, Black et al. 1985, Burns 1991, Heath and Gifford 2002), but many studies have also compared alternative causal models (Dietz et al. 1998, 2007, Stern et al. 1999, Kaiser et al. 2005, Xiao and Dunlap 2007). The current research first assesses alternative conceptual models independently, i.e., new environmental paradigm, connectedness-to-nature, basic value dimensions, norm activation theory, and theory of reasoned action, and then merges them into a comprehensive model combining key elements. We did not attempt to provide complete coverage of all scales and theoretical perspectives used in previous studies, but based our approach on the consistency of patterns that were observed in the past. At the same time, we include a more recently identified proenvironmental concept, connectednessto-nature (Schultz et al. 2004, Mayer and McPherson Frantz 2004), which to date has been less thoroughly employed and assessed.

\section{New environmental paradigm}

The new environmental paradigm (NEP) scale is a widely utilized measure of proenvironmental inclinations (Dunlap and Van Liere 1978, 1984, Dunlap et al. 2000). The NEP is defined by foundational beliefs regarding the nature of the Earth and humanity's relationship to it (Dunlap et al. 2000). It is a sociological concept, tapping the existence of beliefs about the nature of society and its impact on the environment. People that score highly on the NEP scale hold an eco-centric worldview that tends to lead to engagement in proenvironmental behaviors, including support for environmental conservation.

Numerous studies have employed the NEP to score environmental values, attitudes, and beliefs (or, collectively, "the worldview") of the general population and of special interest groups in various jurisdictions. Several studies have found significant relationships between the NEP and proenvironmental behaviors (e.g., Olli et al. 2001, Kortenkamp and Moore 2006). Other studies have demonstrated links between the NEP and other factors considered related to environmental concern, such as environmental knowledge and political ideology (Pierce et al. 1987, Dunlap et al. 2000, Johnson et al. 2004). Our hypothesis is that the NEP scale score and the likelihood to engage in PLC are positively associated.

\section{Connectedness-to-nature}

A more recently developed scale is the connectedness-to-nature (CN) scale (Kals et al. 1999, Schultz 2001, Mayer and McPherson Frantz 2004, Schultz et al. 2004). The CN scale was developed to reflect the bond that an individual has with nature. It is argued that $\mathrm{CN}$ constitutes an extension of the person's own sense of self to include nature. Accordingly, $\mathrm{CN}$ serves as a prerequisite for proenvironmental behavior because "if the self is expanded to include the natural world, behavior leading to the destruction of this world will be experienced as self-destruction" (Roszak 1995, as cited in Mayer and McPherson Frantz 2004:504).

$\mathrm{CN}$ is more psychological than NEP because it represents the individual's personal relationship with the environment and its meaning to one's own self-concept (Frantz et al. 2005). The CN scale reflects a person's affective and experiential relationship with 
the environment, while the NEP scale mainly measures cognitive beliefs about nature. Factual conclusions captured by the NEP scale may lead to environmental activism, but may not generate the same commitment as personal feelings for the environment, which are the focus of the $\mathrm{CN}$ scale. Our hypothesis is that the $\mathrm{CN}$ scale score and the likelihood to engage in PLC are positively associated.

\section{Basic value dimensions}

Values are evaluative beliefs regarding desirable end states (Rokeach 1968, 1973). They transcend specific actions and objects and are tied to the self, serving as personal standards and preferred outcomes. Values are universal but vary in their importance for each individual. As the basic building blocks of cognition, values are fundamental to, and antecedents of, worldviews regarding the environment.

Schwartz (1992, 1994, 1996, 2012) investigated the structure of value systems, arguing for a topology that classifies all human values into 10 value types arrayed across 4 dimensions. We adopted this topology to assess the influence of basic values on the decision to engage in PLC. We used the condensed 15-item scale (Stern et al. 1995) that conforms to the following 4dimensional structure: (1) self-transcendence, representing biospheric and altruistic values; (2) traditionalism, representing family safety and self-discipline; (3) self-enhancement, representing egotistic and hedonistic values; and (4) opennessto-change, relating to self-direction and stimulation (see Appendix 1 for short forms of the questions utilized in this study).

Our first hypothesis is that self-transcendence and openness-tochange are positively associated with proenvironmental worldviews, i.e., NEP and $\mathrm{CN}$, while traditionalism and selfenhancement are negatively associated with them. Our second hypothesis is that self-transcendence and openness-to-change are positively associated with the likelihood to engage in PLC, while traditionalism and self-enhancement are negatively associated with it. The reliability of self-enhancement was somewhat lower than the commonly recommended minimum level (alpha $=0.70$ [Nunnally and Bernstein 1994]). However, we kept self-enhancement in the analysis because of its theoretical importance as one of Schwartz's value dimensions.

\section{Norm activation theory}

Norm activation theory (Schwartz 1970, 1973, 1977) provides a well-supported model for explaining behavioral outcomes. Conceived to explain altruism, it has been used to predict proenvironmental behaviors because these typically entail prosocial and self-sacrificing acts (Heberlein 1972). Many studies have applied norm activation theory as the basis for examining proenvironmental behaviors (e.g., Van Liere and Dunlap 1978, Heberlein and Black 1981, Black et al. 1985, Hopper and Nielson 1991, Vining and Ebreo 1992, Guagnano et al. 1995, Ebreo et al. 1999, Stern et al. 1999). The core of the theory is its focus on moral norms and the conditions under which these norms motivate prosocial behavior. The theory involves three factors, i.e., awareness-of-consequences (AC), ascription-of-responsibility (AR), and personal-norm (PN), that imply that awareness of consequences leads to the acceptance of responsibility, which causes the formation of a personal norm, defined as a personally felt obligation to act to correct a wrong.

Our hypotheses are that both AC and AR are positively related to $\mathrm{PN}$. Further, we hypothesize that $\mathrm{PN}$ is positively related to $\mathrm{NEP}, \mathrm{CN}$, as well as the likelihood of conservation program participation. However because of its low reliability below the commonly recommended minimum level (alpha $=0.70$ [Nunnally and Bernstein 1994]), AR is excluded from subsequent analysis.

\section{Theory of reasoned action}

The theory of reasoned action (Fishbein and Ajzen 1975, Ajzen and Fishbein 1980) is a widely supported model of cognition and is among the most successful theories of persuasion and attitudes. It was developed to provide a stronger explanation for the link between behaviors and attitudes and addressed this through the following relationship between three main components: behavioral-intention (BI) is the result of attitude-toward-the-act (AA) and subjective-norm (SN).

Attitudes, here, are beliefs held by individuals toward a behavioral object, along with an evaluation (good or bad) associated with these beliefs. The model is restricted to explaining voluntary behavior and although behavior itself is not included in the model, behavioral intention is considered approximately identical to actual behavior when under volitional control (Fishbein and Ajzen 1975). The current research dealt with beliefs about environmental outcomes resulting from voluntary participation in a government-sponsored conservation program. Voluntary participation in this conservation program imposes minimal costs or constraints on the individual participant. Because perceived control factors on program participation therefore are limited, the theory of reasoned action (Fishbein and Ajzen 1975, Ajzen and Fishbein 1980) is a more appropriate model than the theory of planned behavior (Ajzen1985, 1991). The $\mathrm{SN}$ is the social expectation of the proenvironmental behavior. Along with this comes the individual's motivation to comply, i.e., the extent to which an individual is inclined to conform to or to ignore the $\mathrm{SN}$.

Our hypotheses are that both AA and $\mathrm{SN}$ are positively related to NEP, $\mathrm{CN}$, as well as the likelihood of conservation program participation. However, because of its low reliability below the commonly recommended minimum level (alpha $=0.70$ [Nunnally and Bernstein 1994]), $\mathrm{SN}$ is excluded from subsequent analysis.

\section{Comprehensive model}

First, each of the conceptual approaches described so far were examined independently to assess their ability to predict environmental conservation. We then merged these approaches to produce one comprehensive model. The combined model is similar to the value-belief-norm theory (Stern et al. 1999) applied to examine public support for environmentalism and social movements, but deviates from it by including $\mathrm{CN}$ and elements of the theory of reasoned action. Further, we include a number of socio-demographic landowner characteristics that may affect outcomes in terms of psychological states and behavior; these include gender, education, political leaning, household income, and the area of the property portion that is eligible for conservation. The last variable is a surrogate for financial incentives achieved through property tax relief (actually received or potentially available) because total tax relief is proportional to the area of the conservation program-eligible portion of the property. 


\section{METHODS}

\section{Private land conservation program and database}

The current study uses participation in a government-sponsored PLC program as an expression of proenvironmental behavior. This study is part of a larger project into PLC programs in Ontario, Canada. The larger project investigated the Conservation Land Tax Incentive Program (CLTIP) and the Managed Forest Tax Incentive Program (MFTIP), both administered by the Ontario Ministry of Natural Resources and Forestry (MNRF). However, because the parameters of the two programs differ, they cannot easily be compared for the purposes of the current study, and we focus on just one program, the CLTIP. This program encourages stewardship of provincially important conservation lands, by providing property tax relief to private landowners who agree to protect the natural heritage features of their properties. Protection of these natural heritage features is achieved by prohibiting land-use activities that are deemed inconsistent with natural heritage objectives such as harvesting timber or nontimber forest products for sale or constructing buildings, and by permitting land-use activities that are deemed consistent with natural heritage objectives such as hiking or hunting. Working lands used for farming, e.g., crop or pasture lands, or for sale (here: sale, barter, or trade) of timber or nontimber forest products are not eligible for this program. CLTIP enrolment is for a renewable one-year period, without penalty if lands are not re-enrolled. Participating landowners are granted $100 \%$ property tax relief for the portion of their land that contains provincially important natural heritage features and therefore is deemed eligible for the program. To be eligible, this portion of land must be 0.2 ha or larger and must have been identified by the MNRF as provincially important for conservation purposes, e.g., must be provincially significant wetlands or habitats of endangered species. The CLTIP allows for the enrolment of lands under control by conservation authorities, which are semigovernmental land conservation institutions; however, we excluded these lands from analysis because conservation authorities are not private landowners in the strict sense.

At the time of this study, the government-maintained CLTIP database contained information on 53,734 program-eligible properties. This number does not represent all private lands in the province that are important for conservation, but is the population of lands identified to date by the MNRF as eligible for the CLTIP. The number of CLTIP eligible lands continues to grow as the MNRF appraises an increasing number of natural heritage features (primarily wetlands). Of the currently CLTIP eligible lands 21,372 (39.8\%) were participating in the CLTIP. The database also contains information on the CLTIP eligible property area, indicating that the area of the eligible lands varied from the minimum 0.2 ha to over 12 ha.

\section{Sampling}

The CLTIP study sample consisted of 800 landowners eligible for the CLTIP (an additional 400 landowners were sampled for the MFTIP but are not included in this study). A scan of the CLTIP database revealed that there were more nonparticipants $(60 \%)$ in the population than participants $(40 \%)$, and also more nonparticipants with smaller eligible land area than participants with smaller eligible land area. Because we sought to investigate the motivations for program participation, we required a suitably large number of participants and reduced over-representation of nonparticipating landowners with smaller eligible land areas. Therefore, instead of random (proportionate) sampling, we used disproportionate, stratified sampling based on participation and area of the eligible lands: We drew equal numbers $(n=400)$ of participating and nonparticipating landowners, while oversampling program participants and undersampling nonparticipants especially among owners of small areas of eligible lands (Appendix 2). This approach led to smaller sampling errors and more stable parameter estimates than random sampling would have. To allow population-level parameter estimates, the data of CLTIP participants and nonparticipants were weighted to make them representative of the CLTIP eligible landowner population.

To protect the privacy of CLTIP participants, MNRF required us to use a sampling procedure that anonymized all program participants. Consequently, the identity of study participants (responders and nonresponders) is unknown to us, unless they self-identified.

\section{Mail survey}

In the summer of 2014, we conducted an anonymous mail survey targeting landowners eligible for the CLTIP (participating and nonparticipating) or participating in the MFTIP. We followed the Dillman et al. (2009) total design method, including enhancements such as the option of a web-based, online version of the questionnaire and provision of a $\$ 5$ cash incentive. Webbased questionnaires provide a potential net increase in response rate, while cash incentives have been found to enhance overall response rates to mail surveys and to reduce response latency (Warriner et al. 1996).

In accordance with the Dillman et al. (2009) method, members of the sample first received an advance letter explaining the study and assuring confidentiality. Shortly thereafter, the questionnaire package was mailed that included a cover letter, the questionnaire, and a postage-paid return envelope. This contact was followed by the mailing of a reminder postcard and then the mailing of two more follow-up questionnaire packages that again included a cover letter, the questionnaire, and a postage-paid return envelope. These additional contacts occurred at three-week intervals and were limited to nonrespondents. In the case of a returned questionnaire, the respondent was sent a thank you letter and no further contacts were made.

\section{Questionnaire}

The mailed questionnaire consisted of 21 pages and 250 questions printed in a $15 \mathrm{~cm}$ x $20 \mathrm{~cm}$ pamphlet format (see Appendix 1 for short forms of the questions utilized in this study). Section 1 of the questionnaire inquired into past and present conservation program participation and characteristics that qualify the land for the programs. Section 2 solicited data regarding landowners' environmental stewardship activities, their stewardship history, and the condition of the natural heritage features on their land. Section 3 asked questions about the need for and performance of governmental conservation programs. Section 4 asked questions about general opinions regarding environmental issues. Section 5 inquired into personal characteristics of study participants Section 6 solicited data on consumer behavior and environmental activism. Finally, study participants were able to indicate whether they were available to participate in follow-up interviews. 
Table 1. Descriptive statistics of study participants.

\begin{tabular}{|c|c|c|c|c|c|}
\hline Variable & & Mean & $\begin{array}{c}\text { Standard } \\
\text { Deviation } \\
\end{array}$ & Range & Reliability $^{\dagger}$ \\
\hline Dependent & Conservation program participation & 0.398 & 0.489 & $0-1$ & NA \\
\hline \multirow[t]{5}{*}{ Participant background } & Gender ${ }^{*}$ & 0.655 & 0.475 & $0-1$ & NA \\
\hline & Education (years) & 14.1 & 2.7 & $10-20$ & NA \\
\hline & Household income (\$) & 93,203 & 51,437 & $\begin{array}{l}<20,000- \\
>180,000\end{array}$ & NA \\
\hline & Political leaning $^{\S}$ & 4.1 & 1.1 & $1-7$ & NA \\
\hline & Eligible property area (ha) & 9.3 & 11.9 & $>0.2->50$ & NA \\
\hline \multirow[t]{4}{*}{ Basic values } & Self-transcendence & 26.7 & 3.9 & $6-30$ & 0.87 \\
\hline & Traditionalism & 13.6 & 1.9 & $3-15$ & 0.79 \\
\hline & Openness-to-change & 11.9 & 2.3 & $3-15$ & 0.69 \\
\hline & Self-enhancement & 10.7 & 2.2 & $3-15$ & 0.61 \\
\hline \multirow[t]{2}{*}{ Worldviews } & New Ecological Paradigm (NEP) & 39.0 & 6.0 & $10-50$ & 0.76 \\
\hline & Connectedness-to-nature $(\mathrm{CN})$ & 53.5 & 8.0 & $14-70$ & 0.86 \\
\hline \multirow[t]{3}{*}{ Norm Activation Theory } & Awareness-of-consequences (AC) & 33.8 & 6.5 & $8-36$ & 0.91 \\
\hline & Ascription-of-responsibility (AR) & 5.6 & 2.0 & $2-10$ & 0.53 \\
\hline & Personal-norm (PN) & 20.3 & 3.4 & $5-25$ & 0.70 \\
\hline \multirow[t]{2}{*}{ Theory of Reasoned Action } & Attitude-toward-the-act (AA) & 30.8 & 7.5 & $9-36$ & 0.96 \\
\hline & Subjective-norm (SN) & 6.8 & 1.8 & $2-10$ & 0.48 \\
\hline
\end{tabular}

${ }^{\dagger}$ Cronbach's Alpha reliability coefficient; ${ }^{\star}$ male $=1$, female $=0 ;{ }^{\S}$ very liberal $=1$, very conservative $=7$

The questionnaire was pretested with eight private landowners of which at least two were eligible for the CLTIP and at least three were eligible for the MFTIP. The landowners were asked for their feedback regarding understanding and relevance of the questions; their comments were used for improving the questions.

\section{Analyses}

Analysis of the data occurred in several phases. In the first phase, we investigated the relationship between basic values, proenvironmental worldviews, and conservation program participation, using standard techniques from correlation and regression analysis. In the second phase, we combined elements of several social-psychological theories of proenvironmental behavior and merged them into one comprehensive model. Analyses were based on two-stage, hierarchical modeling. Analysis began with regressing conservation program participation on proenvironmental worldviews as well as using awareness-of-consequence (AC), personal-norm (PN), and attitude-toward-the-act (AA). Subsequently, socio-demographic landowner characteristics (see Appendix 1) were incorporated into the analysis.

Because of the employed sampling procedure and other measures to protect study participant identity, it is not possible to assess nonresponse bias by comparing responders to nonresponders. However, following the continuum of resistance model (e.g., Lin and Schaeffer 1995), variation between early and late responders may help in understanding characteristics of nonresponders. Accordingly, we divided CLTIP responders into approximate equal halves by postal delivery date of the returned questionnaire (early vs. late) and compared these groups by gender, age, workforce status, household type, educational attainment, and income.

\section{Ethics}

The University of Waterloo Office of Research Ethics has reviewed the larger project, of which this study is part. Full ethics clearance has been granted (ORE\# 19326).

\section{RESULTS}

\section{Response rate and participant profile}

The complete survey (CLTIP and MFTIP) resulted in a response rate of $54.9 \%$, based upon receipt of 598 completed questionnaires and the exclusion of 110 unreachable landowners, e.g., moved, deceased. This response rate is higher than in most studies using similar approaches (see Kaplowitz et al. 2004). We received 267 returns from CLTIP participants and 95 returns from CLTIP eligible nonparticipants, resulting in a response rate of at least $45.3 \%$ for the CLTIP study portion. The exact CLTIP response rate cannot be calculated because we could not confirm whether unreachable landowners were eligible for CLTIP or MFTIP. The analyses presented in this paper are based solely on the CLTIP data.

Early and late responders did not differ significantly by gender $\left(\chi^{2}=2.861, \mathrm{df}=1, p=0.091\right)$, household type $\left(\chi^{2}=9.809, \mathrm{df}=\right.$ $7, p=0.200)$, educational attainment ( $W=5871, p=0.765)$, or income ( $W=4568, p=0.765)$. However, early responders were significantly older than late responders (average: 66.3 years vs. 61.9 years, $t=2.782, \mathrm{df}=201.92, p=0.006$ ); early responders also tended to be more often retired and less often employed (fullor part-time) compared to late responders $\left(\chi^{2}=12.333, \mathrm{df}=6, p\right.$ $=0.055)$. Extrapolation of the study results to the entire CLTIP eligible landowner population should therefore be done with caution, considering that younger, employed landowners might express different opinions and behaviors than older, retired landowners.

The weighted proportion of landowners participating in the CLTIP was 0.398 (Table 1). Of the respondents, $65.5 \%$ were male and the average length of education was 14.1 years, suggesting that a large proportion of participants pursued postsecondary education. Average household income was \$93,203 and respondents generally fell slightly to the conservative side of a seven-point spectrum of political leanings. The average size of the lands eligible for the CLTIP was 9.3 ha. 
Table 2. Correlations among four basic value dimensions, worldviews, and conservation program participation.

\begin{tabular}{|c|c|c|c|c|c|c|}
\hline \multirow[t]{3}{*}{ Variable } & \multicolumn{6}{|c|}{ Correlations $^{\dagger}$} \\
\hline & \multicolumn{4}{|c|}{ Basic value dimensions } & \multicolumn{2}{|c|}{ Worldviews } \\
\hline & $\begin{array}{c}\text { Self- } \\
\text { transcendence }\end{array}$ & Traditionalism & $\begin{array}{l}\text { Openness-to- } \\
\text { change }\end{array}$ & Self-enhancement & $\begin{array}{l}\text { New Ecological } \\
\text { Paradigm (NEP) }\end{array}$ & $\begin{array}{l}\text { Connectedness-to-nature } \\
\text { (CN) }\end{array}$ \\
\hline Traditionalism & $0.535^{*}$ & - & - & - & - & - \\
\hline Openness-to-change & $0.432 *$ & $0.418^{*}$ & - & - & - & - \\
\hline Self-enhancement & $0.376^{*}$ & $0.409^{*}$ & $0.584 *$ & - & - & - \\
\hline New Ecological & $0.580^{*}$ & $0.305^{*}$ & $0.263^{*}$ & $0.150^{*}$ & - & - \\
\hline $\begin{array}{l}\text { Connectedness-to- } \\
\text { nature }(\mathrm{CN})\end{array}$ & $0.579^{*}$ & $0.351^{*}$ & $0.310^{*}$ & $0.252^{*}$ & $0.619^{*}$ & - \\
\hline $\begin{array}{l}\text { Conservation program } \\
\text { participation }\end{array}$ & $0.085^{\mathrm{NS}}$ & $-0.047^{\mathrm{NS}}$ & $0.055^{\mathrm{NS}}$ & $-0.021^{\mathrm{NS}}$ & $0.179^{*}$ & $0.030^{\mathrm{NS}}$ \\
\hline
\end{tabular}

'Spearman rank (basic values); Pearson product moment (worldviews); point biserial (program participation)

${ }^{*} p<0.01$ (one-tailed), ${ }^{\mathrm{NS}} p>0.05$ (one-tailed)

Respondents showed a strong trend for biospheric and altruistic characteristics, scoring 26.7 of a maximum of 30 on the selftranscendence scale (Table 1). They also showed a strong trend for traditional family values, on average scoring 13.6 of a maximum of 15 on the traditionalism scale. The respondents were more centrist in terms of both openness-to-change, at 11.9 of a maximum of 15 , and self-enhancement, at 10.7 of a maximum of 15. Nevertheless, responses on these two scales were skewed toward overall agreement, indicating trends toward selfdetermination and material values as well as a desire for a varied life. On average, respondents were skewed toward agreement with the worldviews represented by both the NEP scale and the $\mathrm{CN}$ scale (Table 1), on average scoring 39.0 of a maximum of 50 and 53.5 of a maximum of 70 , respectively, indicating an overall concern for the natural environment and a feeling of connectedness-to-nature.

Overall, respondents tended to show awareness of environmental problems, on average scoring 33.8 of a maximum of 36 on the AC scale (Table 1). However, respondents were less inclined to accept responsibility for solving environmental problems, on average scoring only 5.6 of a maximum of 20 on the AR scale. Unfortunately, the reliability of this scale $(\alpha=0.53)$ was below standards of accepted reliability and therefore this scale was excluded from further analyses. In contrast to the AR scale, respondents felt a personal obligation to conserve environmental features of their land, scoring 20.3 of a maximum of 25 on the PN scale.

Respondents showed a positive attitude toward environmental stewardship programs such as the CLTIP, on average scoring 30.8 of a maximum of 36 on the AA scale (Table 1). Respondents tended to perceive a social expectation for proenvironmental behavior, on average scoring 6.8 of a maximum of 20 on the SN scale. However, because the reliability of this scale was below acceptable standards, it was also excluded from subsequent analyses. Because in this study we investigate the actual behavior (participation in the CLTIP), we excluded BI from analysis.

\section{Basic values, worldviews, and program participation}

In an initial exploration of data patterns with simple correlations, all four basic value dimensions showed moderate or strong positive intercorrelations (Table 2). Hence, respondents did not seem to see any great contradiction between, for example, being traditional and still in support of equality and social justice, or being materialistic and still being open to change.

Additional data exploration with simple correlation analyses showed that all four basic value dimensions were positively correlated with the two assessed worldviews, the NEP and CN (Table 2). As predicted, self-transcendence was strongly associated with overall dispositions toward proenvironmental worldviews. Also as predicted, openness-to-change was associated with proenvironmental worldviews. However, traditionalism and self-enhancement were associated with these worldviews as well. Against our expectation, openness-to-change was not more strongly associated with proenvironmental worldviews than traditionalism and self-enhancement. This pattern expresses itself similarly for both the NEP scale and the $\mathrm{CN}$ scale, which is also indicated by the high degree of association between the two worldviews $(r=0.619, p<0.01)$.

As expected, the associations between the four basic value dimensions and PLC, as expressed in conservation program participation, were weaker than between worldviews, i.e., NEP scale, and PLC (Table 2). In fact, none of the four basic value dimensions was significantly associated with PLC. Interestingly, though, both self-transcendence $(r=0.085, p=0.062)$ and openness-to-change $(r=0.055, p=0.157)$ trended positively with PLC, while both traditionalism $(r=-0.047, p=0.195)$ and selfenhancement $(r=-0.021, p=0.353)$ showed negative trends. Though these were nonsignificant trends, they reflect our expectation about the associations among basic value dimensions and PLC. Note, that the positive association between the NEP scale and conservation program participation was the only significant one.

Further analyses with multivariable regressions provided deeper insights into the effects of the four value dimensions on proenvironmental worldviews, i.e., NEP and CN. The regressions resulted in significant models that explained $36 \%$ and $31 \%$ of the variance in NEP and CN, respectively (Table 3). Different from the simple correlation analyses, controlling for simultaneous effects of the four basic value dimensions in the multivariable 
Table 3. Regressions of worldviews and conservation program participation on four basic value dimensions.

\begin{tabular}{|c|c|c|c|c|c|c|c|c|c|c|}
\hline \multirow[t]{2}{*}{ Variable } & \multicolumn{3}{|c|}{ New Ecological Paradigm (NEP) } & \multicolumn{3}{|c|}{ Connectedness-to-nature (CN) } & \multicolumn{4}{|c|}{ Conservation program participation } \\
\hline & $B$ & $\begin{array}{c}\text { Standard } \\
\text { error }\end{array}$ & $p$ & $B$ & $\begin{array}{c}\text { Standard } \\
\text { error }\end{array}$ & $p$ & $B$ & $\begin{array}{l}\text { Standard } \\
\text { error }\end{array}$ & $p$ & $\operatorname{Exp}(B)$ \\
\hline Constant & 19.30 & 1.945 & $<0.001$ & 25.99 & 2.647 & $<0.010$ & -0.585 & 0.891 & 0.512 & 0.557 \\
\hline Self-transcendence & 1.226 & 0.103 & $<0.001$ & 1.332 & 0.140 & $<0.010$ & 0.138 & 0.050 & 0.005 & 1.148 \\
\hline Traditionalism & -0.797 & 0.206 & $<0.001$ & -0.656 & 0.280 & 0.020 & -0.263 & 0.099 & 0.008 & 0.769 \\
\hline $\begin{array}{l}\text { Openness-to- } \\
\text { change }\end{array}$ & 0.199 & 0.155 & 0.200 & 0.189 & 0.211 & 0.371 & 0.066 & 0.074 & 0.376 & 1.068 \\
\hline Self-enhancement & -0.424 & 0.158 & 0.007 & -0.123 & 0.215 & 0.565 & -0.069 & 0.073 & 0.344 & 0.934 \\
\hline Goodness-of-fit & \multicolumn{3}{|c|}{$\begin{aligned} & R_{\text {adj }}^{2}=0.36 \\
& F_{(4341)}=49.30 \\
& p<0.010\end{aligned}$} & \multicolumn{3}{|c|}{$\begin{aligned} R_{\text {adj }}^{2} & =0.31 \\
F_{(4341)} & =38.88 \\
p< & 0.010\end{aligned}$} & & \multicolumn{3}{|c|}{$\begin{array}{c}\text { Nagelkerke } R^{2}=0.05 \\
=10.69 \\
p=0.030\end{array}$} \\
\hline
\end{tabular}

regression analyses reveals relationships between the value dimensions and the worldviews that are consistent with our hypotheses: Self-transcendence and openness-to-change showed positive effects while traditionalism and self-enhancement showed negative effects on both NEP and CN. However, openness-to-change was not a significant predictor for worldview and self-enhancement was not a significant predictor for $\mathrm{CN}$. Nevertheless, overall the regression models do suggest a pattern whereby basic value dimensions are contributing to worldviews in theoretically supported and significant ways.

The multivariable, logistic regression of conservation program participation on the four basic value dimensions resulted in a significant model (Table 3). As was the case for the two worldviews and consistent with our hypotheses, self-transcendence and openness-to-change showed positive effects whereas traditionalism and self-enhancement showed negative effects. A one-unit increase on the self-transcendence scale led to a $15 \%$ increase in the odds of conservation program participation (i.e., the ratio of the probability of program participation and of the probability of program nonparticipation), while a one-unit increase on the traditionalism scale led to a $23 \%$ decrease in the odds of conservation program participation. However, the regression model explained only $5 \%$ in the variability of conservation program participation, and the effects of openness-to-change and self-enhancement were not statistically significant. Hence, although it appears that basic values were linked to conservation program participation, much of the variation remained unexplained.

\section{Norm activation and reasoned action}

Regression of $\mathrm{PN}$ on $\mathrm{AC}$ and the two proenvironmental worldviews (NEP and $\mathrm{CN}$ ) resulted in a significant model that explained $27 \%$ of the variation in PN (Table 4). Consistent with our hypotheses, examination of the individual variables showed that both NEP and CN had significant effects on PN. However, $\mathrm{AC}$, one of the key factors of norm activation theory, was not significant. The reason for this lack of significance appears to be that AC was positively associated with both NEP $(r=0.642, p<$ $0.01)$ and $\mathrm{CN}(r=0.370, p<0.01)$. As hypothesized, a regression of PN solely on AC showed a significant positive association $(r$ $=0.370, p<0.01)$ in accordance with norm activation theory.

Inclusion of socio-demographic landowner characteristics in the regression model of $\mathrm{PN}$ led to an increase of explained variation by $1 \%$ (Table 4 ). Among these factors, the only significant one was political leaning, i.e., left vs. right, but its influence was fairly small $(\beta=0.12)$. Neither gender, education, household income, nor eligible property area had a significant effect on PN.

Regression of AA on the two proenvironmental worldviews, i.e., NEP and CN, also resulted in a significant model, explaining 4\% of the variation (Table 4). Examination of the individual variables showed that NEP had a significant effect consistent with our hypothesis, but $\mathrm{CN}$ did not. Inclusion of socio-demographic landowner characteristics in the regression model of AA again led to a minor increase in the explained variation (Table 4). Among these factors, the only significant one was eligible property area, but its influence was small $(\beta=0.13)$. In contrast to the regression model for PN, political leaning had no significant effect.

\section{Combined model}

The initial multivariate, logistic regression of conservation program participation on the two proenvironmental worldviews (NEP and $\mathrm{CN}$ ) as well as attitude and personal norm, resulted in a significant model that explained $23 \%$ of the variation in conservation program participation (Table 5). Consistent with our hypotheses, NEP and AA had significant effects on conservation program participation. $\mathrm{PN}$ did not have a significant effect, but it trended in the expected direction of increasing the odds of conservation program participation. This lack of a statistically significant effect appears to be caused by a positive association of PN with both NEP and CN ( $r=0.52$ and $r=0.43$, respectively, both $p<0.01)$. A logistic regression of $\mathrm{PN}$ on conservation program participation showed a significant positive association $\left(r_{p b}=0.12, p=0.01\right)$. Different from our hypothesis, $\mathrm{CN}$ had a negative effect on the odds of conservation program participation, again likely due to its association with NEP $(r=$ $0.62, p<0.01)$. AA had the strongest effect on conservation program participation; a one-unit increase in AA led to a $13 \%$ increase in the odds of conservation program participation.

The inclusion of socio-demographic landowner characteristics in the multivariate, logistic regression of conservation program participation greatly increased the explained variation to $35 \%$, but the pattern among the four main variables (NEP, CN, PN, and AA) remained largely unchanged (Table 5). In the expanded model, a one-unit increase on the NEP and AA scales led to $8 \%$ and $16 \%$ increases, respectively, in the odds of PLC program participation. Among the socio-demographic landowner 
Table 4. Attitude-behavior models of norm activation and reasoned action.

\begin{tabular}{|c|c|c|c|c|c|c|c|c|c|c|c|c|}
\hline \multirow[t]{3}{*}{ Variable } & \multicolumn{6}{|c|}{ Personal-norm (PN) } & \multicolumn{6}{|c|}{ Attitude-toward-the-act (AA) } \\
\hline & \multicolumn{3}{|c|}{ Base model } & \multicolumn{3}{|c|}{$\begin{array}{c}\text { Base model plus socio- } \\
\text { demographics }\end{array}$} & \multicolumn{3}{|c|}{ Base model } & \multicolumn{3}{|c|}{$\begin{array}{c}\text { Base model plus socio- } \\
\text { demographics }\end{array}$} \\
\hline & $B$ & $\begin{array}{c}\text { Standard } \\
\text { error }\end{array}$ & $p$ & $B$ & $\begin{array}{l}\text { Standard } \\
\text { error }\end{array}$ & $p$ & $B$ & $\begin{array}{c}\text { Standard } \\
\text { error }\end{array}$ & $p$ & $B$ & $\begin{array}{c}\text { Standard } \\
\text { error }\end{array}$ & $p$ \\
\hline Constant & 7.020 & 1.200 & $<0.01$ & 5.160 & 1.760 & $<0.01$ & 20.500 & 2.984 & $<0.01$ & 21.820 & 4.502 & $<0.01$ \\
\hline $\begin{array}{l}\text { Awareness-of- } \\
\text { consequences (AC) }\end{array}$ & 0.037 & 0.030 & 0.22 & 0.034 & 0.030 & 0.26 & - & - & - & - & - & - \\
\hline $\begin{array}{l}\text { New Ecological } \\
\text { Paradigm (NEP) }\end{array}$ & 0.203 & 0.038 & $<0.01$ & 0.225 & 0.038 & $<0.01$ & 0.275 & 0.082 & $<0.01$ & 0.255 & 0.084 & $<0.01$ \\
\hline $\begin{array}{l}\text { Connectedness-to- } \\
\text { nature }(\mathrm{CN})\end{array}$ & 0.077 & 0.025 & $<0.01$ & 0.080 & 0.024 & $<0.01$ & -0.008 & 0.062 & 0.90 & -0.017 & 0.062 & 0.78 \\
\hline Gender & - & - & - & -0.238 & 0.319 & 0.46 & - & - & - & -0.855 & 0.815 & 0.30 \\
\hline Education & - & - & - & -0.037 & 0.061 & 0.54 & - & - & - & 0.051 & 0.156 & 0.74 \\
\hline Household income & - & - & - & $<0.001$ & $<0.001$ & 0.35 & - & - & - & $<0.001$ & $<0.001$ & 0.46 \\
\hline Political leaning & - & - & - & 0.373 & 0.156 & 0.02 & - & - & - & -0.133 & 0.400 & 0.74 \\
\hline $\begin{array}{l}\text { Eligible property } \\
\text { area }\end{array}$ & - & - & - & -0.006 & 0.007 & 0.38 & - & - & - & 0.043 & 0.018 & 0.02 \\
\hline Goodness-of-fit & \multicolumn{3}{|c|}{$\begin{array}{c}R_{\text {adj }}^{2}=0.27 \\
F_{(3,349)}=44.88 \\
p<0.01\end{array}$} & \multicolumn{3}{|c|}{$\begin{array}{c}R_{\text {adj }}^{2}=0.28 \\
F_{(8,353)}=18.61 \\
p<0.01\end{array}$} & \multicolumn{3}{|c|}{$\begin{array}{c}R^{2}=0.04 \\
F_{(2,351)}=8.34 \\
p<0.01\end{array}$} & \multicolumn{3}{|c|}{$\begin{array}{c}R^{2}=0.05 \\
F_{(7,351)}=3.43 \\
p<0.01\end{array}$} \\
\hline
\end{tabular}

characteristics, the only significant one was education and its effect was strong. A one-unit increase in education, i.e., an increase in education by one year, led to a $33 \%$ increase in the odds of conservation program participation. Neither gender, household income, political leaning, nor eligible property area had an effect.

\section{DISCUSSION}

We applied a rigorous, comparative approach to the assessment of elements of various social-psychological theories explaining private landowner participation in a government-sponsored PLC program, contrasting landowners who participate with those who are eligible to participate but do not. To our knowledge, Bieling (2004) is the only other study in the PLC field that has combined elements of different social-psychological concepts and/or models. However, different from our study in which the contributions of the different elements are compared, Bieling (2004) combined all concepts/models into one new model and did not assess the contributions of the individual parts. Although social-psychological concepts such as values, norms, and attitudes have been utilized in other studies (e.g., Moon et al. 2012, Raymond and Schneider 2014, Kusmanoff et al. 2016), they have not been systematically applied to the same data set and their individual contributions investigated in this way. The results of our study illustrate the complex relationships among basic values, worldviews, norms, attitudes, and behaviors emphasizing the importance of proenvironmental worldviews, i.e., NEP, and of formal education for increasing the likelihood of enrolment in a government-sponsored PLC program. Against expectation, neither personal norms, household income, political leaning, nor the size of the eligible property area were found to be important in directly determining the decision to enrol in PLC programs. However, an association of political leaning with personal obligation for PLC was found. To our knowledge, the current study is the first to systematically compare alternative concepts from social psychology such as basic values, worldviews, norms, and attitudes and their relationships with PLC.
Although some basic value dimensions are clearly linked with proenvironmental worldviews, i.e., self-transcendence and traditionalism, our results suggest that there is no strong direct link with the decision of PLC program participation. However, it is important to be aware of the serial links from basic values to worldviews to behaviors. Ignoring these serial relationships might lead to the spurious conclusion that basic values play no role in the emergence of PLC participation. Our results align with the basic formulation of belief-attitude-behavior relationships as described by Fishbein and Ajzen (1975), predicting a weak relationship of beliefs with behavior, but stronger relationships of beliefs with attitudes and of attitudes with behaviors. In comparison, Slimak and Dietz (2006) used models based on value-belief-norm theory to investigate the influence of values and worldviews on ecological risk perception. They suggest that values affect risk perception directly and indirectly through their effect on worldviews that in turn are linked to risk perception. Unfortunately, beliefs and worldviews are frameworks of understanding that are difficult to modify and therefore may offer less opportunity for increasing PLC participation.

We found a landowner's positive attitude toward the CLTIP to be important for the likelihood of enrolment into the program. Additionally, formal education was associated with the decision to engage in this conservation program. Uliczka et al. (2004) determined that educational attainment was an important factor in determining nonindustrial forest owners' attitudes toward biodiversity conservation in Sweden. Uliczka et al. (2004) differentiated between various kinds of education and found that forestry-related education was related to more knowledge about conservation, but not to attitude toward it. General education, however, interacted with gender and age group to determine attitude toward conservation, with younger women of higher education having the most positive attitude (Uliczka et al. 2004). Conradie et al. (2013) found that farmers' duration of formal education was associated with an increase in the probability of participation in a biodiversity conservation initiative in South 
Table 5. Combined model of conservation program participation.

\begin{tabular}{|c|c|c|c|c|c|c|c|c|}
\hline \multirow[t]{3}{*}{ Variable } & \multicolumn{8}{|c|}{ Conservation program participation } \\
\hline & \multicolumn{4}{|c|}{ Base model } & \multicolumn{4}{|c|}{ Base model plus socio-demographics } \\
\hline & $B$ & $\begin{array}{l}\text { Standard } \\
\text { error }\end{array}$ & $p$ & $\operatorname{Exp}(B)$ & $B$ & $\begin{array}{l}\text { Standard } \\
\text { error }\end{array}$ & $p$ & $\operatorname{Exp}(B)$ \\
\hline Constant & -5.217 & 1.21 & $<0.01$ & 0.005 & -10.637 & 2.08 & $<0.01$ & $<0.001$ \\
\hline New Ecological Paradigm (NEP) & 0.069 & 0.032 & 0.03 & 1.072 & 0.079 & 0.039 & 0.04 & 1.082 \\
\hline Connectedness-to-nature $(\mathrm{CN})$ & -0.045 & 0.022 & 0.04 & 0.956 & -0.060 & 0.026 & 0.02 & 0.942 \\
\hline Personal-norm (PN) & 0.038 & 0.047 & 0.42 & 1.039 & 0.072 & 0.058 & 0.22 & 1.074 \\
\hline Attitude-toward-the-act (AA) & 0.119 & 0.021 & $<0.01$ & 1.127 & 0.146 & 0.026 & $<0.01$ & 1.157 \\
\hline Gender & - & - & - & - & 0.330 & 0.321 & 0.30 & 1.391 \\
\hline Education & - & - & - & - & 0.287 & 0.076 & $<0.01$ & 1.332 \\
\hline Household income & - & - & - & - & $<0.001$ & $<0.001$ & 0.37 & 1.000 \\
\hline Political leaning & - & - & - & - & 0.090 & 0.151 & 0.55 & 1.094 \\
\hline Eligible property area & - & - & - & - & 0.022 & 0.013 & 0.10 & 1.022 \\
\hline Goodness-of-fit & \multicolumn{4}{|c|}{$\begin{array}{c}\text { Nagelkerke } R^{2}=0.23 \\
=52.91 \\
p=<0.01\end{array}$} & \multicolumn{4}{|c|}{$\begin{array}{c}\text { Nagelkerke } R^{2}=0.35 \\
=73.66 \\
p=<0.01\end{array}$} \\
\hline
\end{tabular}

Africa. These findings highlight the critical need to increase landowners' levels of understanding of conservation challenges and of possible solutions that are within their practical reach (Shaw et al. 2012, Cook and Ma 2014). Education from kindergarten to grade 12 to the postsecondary school system may be crucial contributions to increase these levels of environmental understanding and engagement with conservation initiatives (Hungerford and Volk 1990, Downing and Finley 2005, Shaw et al. 2012). Especially important in this regard may be that environmental education in the formal school system should not only strive to provide people with knowledge about the natural environment, but to help them acquire positive attitudes toward this environment and enable them to take action in the pursuit of resolving environmental conflicts (Hungerford and Volk 1990).

Political leaning was not found to directly influence the decision to enrol in this government-sponsored PLC program. This is noteworthy because the common expectation might be that conservative-leaning landowners would be less inclined to engage in a government program that might be perceived to limit private property rights and increase governmental spending on the environment (McCright et al. 2014). However, Blasiak et al. (2015), in their study of marine ecosystem services, also found that political leaning did not explain much of the readiness to engage in ecosystem service conservation. This is in contrast, though, with our finding that traditionalism is negatively related to proenvironmental worldviews and participation in the CLTIP. We believe that an explanation may be found in the details of landowners' personality characteristics. The traditionalism basic value dimension embodies a person's focus on immediate family and on self-reliance, which is somewhat opposed to an outward orientation on society. Using the HEXACO model of six basic personality dimensions (Ashton and Lee 2008), Hilbig et al. (2013) found that the honesty-humility dimension provides a link between social cooperativeness and proenvironmental behaviors. Social cooperativeness, however, may stand in contrast to the focus on immediate family and self-reliance as represented by traditionalism. Political leaning is unrelated to traditionalism in our study (M. Drescher, unpublished data). It is therefore possible that, although political leaning is unrelated to the likelihood to enrol in the CLTIP, increasing traditionalism has a negative effect on the likelihood to enrol in this PLC program.

Despite the above, our results show that increasing political conservatism was related to the experience of an increasing personal obligation to preserve the environmental features on one's land. This experience of a personal obligation to conservation could be consistent with a conservative political leaning and with a high score on traditionalism, if a landowner can achieve conservation without participation in a governmental program (Raymond and Schneider 2014). This finding is consistent with the results by Olive and Raymond (2010) who found that politically conservative opinions about property rights do not have to be in opposition to positive norms regarding species-at-risk protection, and with Blankenau et al. (2007) who found strong support for environmental conservation among political conservatives as well as liberal party followers in the USA. Interestingly, a study by Selinske et al. (2015) indicates that personal norms regarding conservation were important motivators for enrolment into a government PLC program. Selinske et al. (2015) found that so-called conservation values were the strongest motivators for private landowners to join a PLC program in South Africa. However, a review of their survey items suggests that these conservation values overlap largely with personal norms, i.e., the experience of a personal obligation to PLC. These findings may highlight opportunities for nongovernmental organizations for supporting the conservation activities of private landowners who are disinclined to engage with governmental programs.

In our analysis, the PLC program eligible property area was a proxy for the financial benefit of program enrolment because the total tax incentive is proportional to the portion of the land enrolled into the program. Of course, an assessment of net financial benefit should also account for opportunity costs of program enrolment (Layton and Siikamäki 2009). However, opportunity costs for participation in the CLTIP are very small, if any; the CLTIP is focused on nonworking lands and therefore the prohibition of commercial use of the land (e.g., no agriculture, no managed forests) should have very limited financial impacts. 
Also, because the CLTIP enrolment period is just one year and no penalties are levied if eligible property areas are not re-enrolled, commercial use in the near future, e.g., timber harvest or residential development, might still be possible. Consequently, the net financial benefit of CLTIP enrolment should mainly be a function of the total tax incentive.

Because the total tax incentive is increasing with the eligible property area, we expected a positive relationship between eligible property area and PLC program participation. However, we did not find such an effect, which may be explained by some of the specifics of the CLTIP. The vast majority of eligible property areas are of modest size and many landowners might consider the financial incentives to be fairly small in absolute terms. If eligible property areas would have been larger, a significant effect might have emerged. Ernst and Wallace (2008) found that owners of larger land holdings ( $>118$ ha) were more likely to engage in commercial agriculture and found financial motivators for conservation more important than owners of smaller land holdings $(<6 \mathrm{ha})$ who worked more toward the protection of natural areas and open space.

Farmer et al. (2016) in research on a state tax-incentivized PLC program in Indiana, USA, found that landowners' implementation of conservation management strategies, e.g. invasive species removal or habitat development, increased with area enrolled in the PLC program. The landowners in our study might have been more alike the owners of smaller landholdings in the Ernst and Wallace (2008) study, but this is speculation. The average land area enrolled in the CLTIP ( 9 ha) is larger than the size of smaller landholdings in the Ernst and Wallace (2008) study ( $<6 \mathrm{ha}$ ), is larger than forest holdings of most family forest owners in the U.S. ( $>70 \%$ own $<4$ ha; Butler 2008), and is larger than the average area of land enrolled in a payment for ecosystem services program for Finnish nonindustrial private forest owners (= 6 ha: Layton and Siikamäki 2009). It is smaller, though, than the median land area enrolled in a PLC program by nonindustrial woodlot owners in Indiana, USA (Farmer et al. 2016). In conclusion, the average area enrolled in the CLTIP is certainly not much out of line with other situations. Previous studies delivered inconsistent results with regard to the effect of landholding size on PLC program enrolment, with some studies finding positive effects (Kauneckis and York 2009) and other studies finding no effect (Kamal et al. 2015b). Despite all this, eligible property area might have had an indirect effect on CLTIP participation because it had a positive effect on the attitude toward the conservation program, which was associated with program enrolment.

Many earlier studies on PLC programs have focused on working lands. These working lands can be a major or supplemental source of income for their owners or can be a hobby-like activity (e.g., Sorice et al. 2012, Urquhart et al. 2012). Other than income generation, ownership motives can include aesthetics, recreation, community values, conservation, hunting or fishing, and residential (Hallikainen et al. 2010, Plieninger et al. 2012, Howley 2013). Not surprisingly, studies on landowners that are likely to use their land for income generation, have found that financial incentives, especially their size and conditions, are important when deciding on enrolment in conservation programs (Koontz 2001, Kabii and Horwitz 2006, Sorice et al. 2013). Our study focused entirely on nonworking lands. It may therefore be unsurprising that financial motives did not play a large role in this study. This result echoes the findings by Farmer et al. (2015) regarding the low importance of financial benefits of conservation easements for private landowners who do not strongly rely on their land for income.

A previous study by Farmer et al. (2011) investigated factors related to private landowners' decision to put a conservation easement on their land. While the CLTIP is different from conservation easements in several respects, such as the duration of the commitment and the extent to which land uses may be allowed (Owley and Rissman 2016), both types of conservation tools are voluntary, lead to property tax advantages, and largely aim to keep the targeted land in its current state. Farmer et al. (2011) found that place attachment was the most important factor for private landowners to place a conservation easement on their land. This factor was followed in importance by societalenvironmental motivators. Interestingly, financial incentives were the least important of all factors considered. The concepts considered in our study are more closely tied to socialpsychological theory than the motivators utilized by Farmer et al. (2011) and therefore direct comparison is difficult. However, Farmer et al.'s (2011) societal-environmental motivators bear a liking to the NEP that was significantly related to CLTIP participation in our study. Also in our study financial incentives, i.e., property tax reductions, were of lesser importance compared to most other factors. It should be pointed out, though, that financial benefits might still be instrumental for achieving other, higher ranked goals (Ernst and Wallace 2008).

The CLTIP uptake rate of approximately $40 \%$ compares favorably with the participation rates in cost-share programs by U.S. private forest owners (U.S. average $=17 \%$; Jacobson et al. 2009). However, it is important to recall that the CLTIP is specifically targeted at landowners who hold land that is of special natural heritage value as identified by the MNRF; an "ordinary" woodlot does not qualify for the CLTIP. MNRF is contacting every eligible landowner by mail regarding the high value of the natural heritage features on their property. Awareness of this fact might increase landowners' willingness to program participation and at least partially explain the relatively high participation rate compared to U.S. cost-share programs. However, we stress that approximately $60 \%$ of landowners who are eligible for participation in the CLTIP, are not participating. To us, this suggests that important factors must exist that prevent private landowners from participating in this governmental conservation program.

\section{CONCLUSION}

We rigorously applied several social-psychological approaches to investigate factors that may facilitate or prohibit private landowners from participation in a government-sponsored conservation program for nonworking lands. We then compared the contributions of these approaches to the explanation of conservation program participation. Our results emphasize the importance of a proenvironmental worldview and of formal education for the decision to enrol into this program. Political leaning was unrelated to conservation program participation while traditionalism as a basic value dimension was negatively related to program participation. Interestingly though, a 
conservative political leaning was related to the feeling of personal obligation to protect environmental features on private land. Our results emphasize the association between formal education and achievement of conservation goals on private land through governmental programs for nonworking lands. However, our results also suggest intriguing opportunities for supporting conservation-minded landowners that are disinclined to engage in governmental programs.

Responses to this article can be read online at: http://www.ecologyandsociety.org/issues/responses. $\mathrm{php} / 9118$

\begin{abstract}
Acknowledgments:
We gratefully acknowledge the landowners who participated in this study, who generously have given of their time, and who have shared their knowledge and opinions. We thank the Ministry of Natural Resources and Forestry for its support of this research. Finally, we are thankful for the comments by two anonymous reviewers and the editors that helped us in improving this manuscript. This research has been made possible financially through a grant from the Social Sciences and Humanities Research Council, file number 430-2012-458.
\end{abstract}

\section{LITERATURE CITED}

2010 Biodiversity Indicators Partnership. 2010. Biodiversity indicators and the 2010 target: outputs, experiences and lessons learnt from the 2010 Biodiversity Indicators Partnership. Technical Series No. 53. Secretariat of the Convention on Biological Diversity, Montréal, Québec, Canada. [online] URL: https:// www.cbd.int/doc/publications/cbd-ts-53-en.pdf

Ajzen, I. 1985. From intentions to actions: a theory of planned behavior. Pages 11-39 in J. Kuhl and J. Beckmann, editors. Action control. From cognition to behavior. Springer, Berlin, Germany. http://dx.doi.org/10.1007/978-3-642-69746-3_2

Ajzen, I. 1991. The theory of planned behavior. Organizational Behavior and Human Decision Processes 50:179-211. http://dx. doi.org/10.1016/0749-5978(91)90020-T

Ajzen, I., and M. Fishbein. 1980. Understanding behaviors and predicting social behavior. Prentice-Hall, Englewood Cliffs, New Jersey, USA.

Ashton, M. C., and K. Lee. 2008. The prediction of honestyhumility-related criteria by the HEXACO and five-factor models of personality. Journal of Research in Personality 42(5):1216-1228. http://dx.doi.org/10.1016/j.jrp.2008.03.006

Bieling, C. 2004. Non-industrial private-forest owners: possibilities for increasing adoption of close-to-nature forest management. European Journal of Forest Research 123 (4):293-303. http://dx.doi.org/10.1007/s10342-004-0042-6

Black, J. S., P. C. Stern, and J. T. Elworth. 1985. Personal and contextual influences of household energy adaptations. Journal of Applied Psychology 70:3-21. http://dx.doi.org/10.1037/0021-9010.70.1.3
Blankenau, J., M. Snowden, and M. Langan. 2007. Understanding environmentalism in a red, agricultural state: the impact of political party identification and place of residence. Sociological Spectrum 28(1):55-80. http://dx.doi. org/10.1080/02732170701675201

Blasiak, R., N. Yagi, H. Kurokura, K. Ichikawa, K. Wakita, and A. Mori. 2015. Marine ecosystem services: perceptions of indispensability and pathways to engaging citizens in their sustainable use. Marine Policy 61:155-163. http://dx.doi. org/10.1016/j.marpol.2015.08.005

Brook, A., M. Zint, and R. de Yong. 2003. Landowners' responses to an endangered species act listing and implications for encouraging conservation. Conservation Biology 17:1638-1649. http://dx.doi.org/10.1111/j.1523-1739.2003.00258.x

Burns, S. M. 1991. Social psychology and the stimulation of recycling behaviors: the block leader approach. Journal of Applied Social Psychology 21:611-629. http://dx.doi.org/10.1111/j.1559-1816.1991. $\underline{\mathrm{tb} 00539 . \mathrm{x}}$

Butler, B. J. 2008. Family forest owners of the United States, 2006. General Technical Report NRS-27. U.S. Forest Service, Northern Research Station, Newtown Square, Pennsylvania, USA.

Conradie, B., M. Treurnicht, K. Esler, M. Gaertner. 2013. Conservation begins after breakfast: the relative importance of opportunity cost and identity in shaping private landholder participation in conservation. Biological Conservation 158:334-341. http://dx.doi.org/10.1016/j.biocon.2012.08.028

Cook, S. L., and Z. Ma. 2014. The interconnectedness between landowner knowledge, value, belief, attitude, and willingness to act: policy implications for carbon sequestration on private rangelands. Journal of Environmental Management 134:90-99. http://dx.doi.org/10.1016/j.jenvman.2013.12.033

Dietz, T., A. Dan, and R. Shwom. 2007. Support for climate change policy: some psychological and social structural influences. Rural Sociology 72:185-214.

Dietz, T., and P. C. Stern, editors. 2002. New tools for environmental protection: education, information and voluntary measures. National Academic Press, Washington, D.C., USA.

Dietz, T., P. C. Stern and G. A. Guagnano. 1998. Social structural and social psychological bases of environmental concern. Environment and Behavior 30(4):450-471. http://dx.doi. org/10.1177/001391659803000402

Dillman D. A., J. D. Smyth, and L. M. Christian. 2009. Internet, mail, and mixed-mode surveys: the tailored design method. Third edition. Wiley, Hoboken, New Jersey, USA.

Downing, A. K., and J. C. Finley. 2005. Private forest landowners: what they want in an educational program. Journal of Extension 43(1). http://www.joe.org/joe/2005february/rb4.php

Drescher, M. 2014. What is it like to take care of the land? Toward an understanding of private land conservation. Rural Society 23 (2):117-132. http://dx.doi.org/10.5172/rsj.2014.23.2.117

Dunlap, R. E., and K. Van Liere. 1978. The "new environmental paradigm." Journal of Environmental Education 9:10-19. http:// dx.doi.org/10.1080/00958964.1978.10801875 
Dunlap, R. E., and K. Van Liere. 1984. Commitment to the dominant social paradigm and concern for environmental quality. Social Science Quarterly 65:1013-1028.

Dunlap, R. E., K. D. Van Liere, A. G. Mertig, and R. E. Jones. 2000. New Trends in Measuring Environmental Attitudes: measuring endorsement to the New Ecological Paradigm: a revised NEP scale. Journal of Social Issues 56:425-442. http://dx. doi.org/10.1111/0022-4537.00176

Ebreo, A., J. Hershey, and J. Vining. 1999. Reducing solid waste. Linking recycling to environmentally responsible consumerism. Environment and Behavior 31:107-135. http://dx.doi. org/10.1177/00139169921972029

Ernst, T., and G. N. Wallace. 2008. Characteristics, motivations, and management actions of landowners engaged in private land conservation in Larimer County, Colorado. Natural Areas Journal 28(2):109-120. http://dx.doi.org/10.3375/0885-8608(2008)28[109: cmamao]2.0.co:2

Farmer, J. R., D. Knapp, and G. M. Benton. 2007. An elementary school environmental education field trip: long-term effects on ecological and environmental knowledge and attitude. Journal of Environmental Education 38(3):33-42. http://dx.doi.org/10.3200/ joee. 38.3.33-42

Farmer, J. R., D. Knapp, V. J. Meretsky, C. Chancellor, and B. C. Fischer. 2011. Motivations influencing the adoption of conservation easements. Conservation Biology 25(4):827-834. http://dx.doi.org/10.1111/j.1523-1739.2011.01686.x

Farmer, J. R., Z. Ma, M. Drescher, E. Knackmuhs, and S. L. Dickinson. 2016. Private landowners, voluntary conservation programs, and implementation of conservation friendly land management practices. Conservation Letters 10:58-66. http://dx. doi.org/10.1111/conl.12241

Farmer, J. R., V. Meretsky, D. Knapp, C. Chancellor, and B. C. Fisher. 2015. Why agree to a conservation easement? Understanding the decision of conservation easement granting. Landscape and Urban Planning 138:11-19. http://dx.doi. org/10.1016/j.landurbplan.2015.01.005

Fishbein, M., and I. Ajzen. 1975. Belief, attitude, intention, and behavior: an introduction to theory and research. Addison-Wesley, Reading, Massachusetts, USA.

Frantz, C., F. S. Mayer, C. Norton, and M. Rock. 2005. There is no " $i$ " in nature: the influence of self-awareness on connectedness to nature. Journal of Environmental Psychology 25:427-436. http:// dx.doi.org/10.1016/j.jenvp.2005.10.002

Government of Canada. 2002. Species at Risk Act. (S.C. 2002. c. 29). Government of Canada, Ottawa, Ontario, Canada.

Government of Ontario. 2007. Endangered Species Act. S.O. 2007. c. 6. Government of Ontario, Toronto, Ontario, Canada.

Guagnano, G., P. C. Stern, and T. Dietz. 1995. Influences on attitude-behavior relationships: a natural experiment with curbside recycling. Environment and Behavior 27:699-718. http:// dx.doi.org/10.1177/0013916595275005

Hallikainen, V., M. Hyppönen, L. Pernu, and J. Puoskari. 2010. Family forest owners' opinions about forest management in northern Finland. Silva Fennica 44(2):363-384. http://dx.doi. org/10.14214/sf.158

Heath, Y., and R. Gifford. 2002. Extending the theory of planned behavior: predicting the use of public transportation. Journal of Applied Social Psychology 32:2154-2189. http://dx.doi.org/10.1111/ j.1559-1816.2002.tb02068.x

Heberlein, T. A. 1972. The land ethic realized: some social psychological explanations for changing environmental attitudes. Journal of Social Issues 28:79-87. http://dx.doi.org/10.1111/ j.1540-4560.1972.tb00047.x

Heberlein, T. A., and J. S. Black. 1981. Cognitive consistency and environmental action. Environment and Behavior 13:717-734. http://dx.doi.org/10.1177/0013916581136005

Hilbig, B. E., I. Zettler, M. Moshagen, and T. Heydasch. 2013. Tracing the path from personality - via cooperativeness - to conservation. European Journal of Personality 27(4):319-327. http://dx.doi.org/10.1002/per.1856

Hoffman, A. J, H. C. Riley, J. G. Troast, Jr., M. H. Bazerman. 2002. Cognitive and institutional barriers to new forms of cooperation on environmental protection: insights from Project XL and habitat conservation plans. American Behavioral Scientist 45(5):820-845. http://dx.doi.org/10.1177/0002764202045005006

Hooper, D. U., F. S. Chapin III, J. J. Ewell, A. Hector, P. Inchausti, S. Lavorel, J. H. Lawton, D. M. Dodge, L. Moreau, S. Naeem, B. Schmid, H. Setälä, A. J. Symstad, J. Vandermeer, and D. A. Wardle. 2005. Effects of biodiversity on ecosystem functioning: a consensus of current knowledge. Ecological Monographs 75:3-35. http://dx.doi.org/10.1890/04-0922

Hopper, J. R., and J. M. Nielson. 1991. Recycling as altruistic behavior: normative and behavioral strategies to expand participation in a community recycling program. Environment and Behavior 23:195-220. http://dx.doi.org/10.1177/0013916591232004

Howley, P. 2013. Examining farm forest owners' forest management in Ireland: the role of economic, lifestyle and multifunctional ownership objectives. Journal of Environmental Management 123:105-112. http://dx.doi.org/10.1016/j. jenvman.2013.03.013

Hungerford, H. R., and T. L. Volk. 1990. Changing learner behavior through environmental education. Journal of Environmental Education 21(3):8-21. http://dx.doi. org/10.1080/00958964.1990.10753743

Jackson-Smith, D., U. Kreuter, and R. S. Krannich. 2005. Understanding the multidimensionality of property rights orientations: evidence from Utah and Texas Ranchers. Society and Natural Resources 18(7):587-610. http://dx.doi. org/10.1080/08941920590959578

Jacobson, M. G., T. J. Straka, J. L. Greene, M. A. Kilgore, S. E. Danield. 2009. Financial incentive programs' influence in promoting sustainable forestry in the Northern Region. Northern Journal of Applied Forestry 26(20):61-67.

Johnson, C. Y., J. Bowker, and H. K. Cordell. 2004. Ethic variation in environmental belief and behavior: an examination of the new ecological paradigm in a social psychological context. Environment and Behavior 36:157-186. http://dx.doi. org/10.1177/0013916503251478 
Kabii, T., and P. Horwitz. 2006. A review of landholder motivations and determinants for participation in conservation covenanting programmes. Environmental Conservation 33 (1):11-20. http://dx.doi.org/10.1017/s0376892906002761

Kaiser, F. G., G. Hübner, and F. X. Bogner. 2005. Contrasting the theory of planned behavior with the value-belief-norm model in explaining conservation behavior. Journal of Applied Social Psychology 35:2150-2170. http://dx.doi.org/10.1111/j.1559-1816.2005. $\underline{\text { tb02213.x }}$

Kals, E., D. Schumacher, and L. Montada. 1999. Emotional affinity toward nature as a motivational basis to protect nature. Environment and Behavior 31:178-202. http://dx.doi. org/10.1177/00139169921972056

Kamal, S., M. Grodzińska-Jurczak, and G. Brown. $2015 a$. Conservation on private land: a review of global strategies with a proposed classification system. Journal of Environmental Planning and Management 58(4):576-597. http://dx.doi. org/10.1080/09640568.2013.875463

Kamal, S., M. Koćor, and M. Grodzińska-Jurczak. $2015 b$. Conservation opportunity in biodiversity conservation on regulated private lands: factors influencing landowners' attitude. Environmental Science and Policy 54:287-296. http://dx.doi. org/10.1016/j.envsci.2015.07.023

Kaplowitz, M. D., T. D. Hadlock, and R. Levine. 2004. A comparison of web and mail survey response rates. Public Opinion Quarterly 68(1):94-101. http://dx.doi.org/10.1093/poq/nfh006

Kauneckis, D., and A. M. York. 2009. An empirical evaluation of private landowner participation in voluntary forest conservation programs. Environmental Management 44:468-484. http://dx.doi.org/10.1007/s00267-009-9327-3

Koontz, T. M. 2001. Money talks? But to whom? Financial versus nonmonetary motivations in land use decisions. Society \& Natural Resources 14:51-65. http://dx.doi.org/10.1080/08941920117246

Kortenkamp, K. V., and C. F. Moore. 2006. Time, uncertainty, and individual differences in decisions to cooperate in resource dilemmas. Personality and Social Psychology Bulletin 32:603-615. http://dx.doi.org/10.1177/0146167205284006

Kusmanoff, A. M., M. J. Hardy, F. Fidler, G. Maffey, C. Raymond, M. S. Reed, J. A. Fitzsimons, and J. A. Bekessy. 2016. Framing the private land conservation conversation: strategic framing of the benefits of conservation participation could increase landholder engagement. Environmental Science and Policy 61:124-128. http://dx.doi.org/10.1016/i.envsci.2016.03.016

Larson, L. R., R. C. Stedman, C. B. Cooper, and D. J. Decker. 2015. Understanding the multi-dimensional structure of proenvironmental behavior. Journal of Environmental Psychology 43:112-124. http://dx.doi.org/10.1016/j.jenvp.2015.06.004

Layton, D. F., and J. Siikamäki. 2009. Payments for ecosystem services programs: predicting landowner enrollment and opportunity cost using a beta-binomial model. Environmental and Resource Economics 44(3):415-439. http://dx.doi.org/10.1007/ $\underline{\text { s10640-009-9293-5 }}$

Liebe, U., and P. Preisendörfer. 2010. Rational choice theory and the environment: variants, applications, and new trends. Pages
141-157 in M. Gross and H. Heinrichs, editors. Environmental sociology: European perspectives and interdisciplinary challenges. Springer, New York, New York, USA. http://dx.doi. org/10.1007/978-90-481-8730-0_9

Lin, I.-F., and N. C. Schaeffer. 1995. Using survey participants to estimate the impact of nonparticipation. Public Opinion Quarterly 59(2):236-258. http://dx.doi.org/10.1086/269471

Mayer, F. S., and C. McPherson Frantz. 2004. The connectedness to nature scale: a measure of individuals' feeling in community with nature. Journal of Environmental Psychology 24:503-515. http://dx.doi.org/10.1016/j.jenvp.2004.10.001

McCright, A. M., C. Xiao, and R. E. Dunlap. 2014. Political polarization on support for government spending on environmental protection in the USA, 1974-2012. Social Science Research 48:251-260. http://dx.doi.org/10.1016/j.ssresearch.2014.06.008

Moon, K., N. Marshall, and C. Cocklin. 2012. Personal circumstances and social characteristics as determinants of landholder participation in biodiversity conservation programs. Journal of Environmental Management 113:292-300. http://dx. doi.org/10.1016/j.jenvman.2012.09.003

Nawrotzki, R. J. 2012. The politics of environmental concern: a cross-national analysis. Organization and Environment 25 (3):286-307. http://dx.doi.org/10.1177/1086026612456535

Nooney, J. G., E. Woodrum, T. J. Hoban, and W. B. Clifford. 2003. Environmental worldview and behavior: consequences of dimensionality in a survey of North Carolinians. Environment and Behavior 35(6):763-783. http://dx.doi.org/10.1177/0013916503256246

Norton, D. A. 2000. Conservation biology and private land: shifting the focus. Conservation Biology 14:1221-1223. http://dx. doi.org/10.1046/j.1523-1739.2000.01451.x

Nunnally, J., and L. Bernstein. 1994. Psychometric theory. McGraw-Hill, New York, New York, USA.

Olive, A., and L. Raymond. 2010. Reconciling norm conflict in endangered species conservation on private land. Natural Resources Journal 50(2):431-454.

Olli, E., G. Grendstad, and D. Wollebaek. 2001. Correlates of environmental behaviour: bringing back social context. Environment and Behavior 33:181-208. http://dx.doi. org/10.1177/0013916501332002

Owley, J., and A. R. Rissman. 2016. Trends in private land conservation: increasing complexity, shifting conservation purposes and allowable private land uses. Land Use Policy 51:76-84. http://dx.doi.org/10.1016/j.landusepol.2015.10.026

Pierce, J. C., N. P. Lovrich Jr, T. Tsurutani, and T. Abe. 1987. Culture, politics and mass publics: traditional and modern supporters of the new environmental paradigm in Japan and the United States. Journal of Politics 49:54-79. http://dx.doi. org/10.2307/2131134

Plieninger, T., S. Ferranto, L. Huntsinger, M. Kelly, and C. Getz. 2012. Appreciation, use, and management of biodiversity and ecosystem services in California's working landscapes. Environmental Management 50(3):427-440. http://dx.doi.org/10.1007/ $\underline{\mathrm{s} 00267-012-9900-\mathrm{Z}}$ 
Raymond, L., and L. U. Schneider. 2014. Personal moral norms and attitudes toward endangered species policies on private land. Conservation and Society 12(1):1-15. http://dx.doi. org/10.4103/0972-4923.132115

Rokeach, M. 1968. Beliefs, attitudes and values. Jossey-Bass, San Francisco, California, USA.

Rokeach, M. 1973. The nature of human values. The Free Press, New York, New York, USA.

Schultz, P. W. 2001. Assessing the structure of environmental concern: concern for the self, other people and the biosphere. Journal of Environmental Psychology 21:327-339. http://dx.doi. org/10.1006/jevp.2001.0227

Schultz, P. W., C. Shriver, J. J. Tabanico, and A. M. Khazian. 2004. Implicit connections with nature. Journal of Environmental Psychology 24:31-42. http://dx.doi.org/10.1016/S0272-4944(03) 00022-7

Schwartz, S. H. 1970. Elicitation of moral obligation and selfsacrificing behavior: an experimental study of volunteering to be a bone marrow donor. Journal of Personality and Social Psychology 15:283-293. http://dx.doi.org/10.1037/h0029614

Schwartz, S. H. 1973. Normative explanations for helping behavior: a critique, proposal, and empirical test. Journal of Experimental Social Psychology 9:349-364. http://dx.doi. org/10.1016/0022-1031(73)90071-1

Schwartz, S. H. 1977. Normative influences on altruism. Pages 221-279 in L. Berkowitz, editor. Advances in experimental social psychology. Volume 10. Academic Press, New York, New York, USA. http://dx.doi.org/10.1016/s0065-2601(08)60358-5

Schwartz, S. H. 1992. Universals in the content and structure of values: theoretical advances and empirical tests in 20 countries. Advances in Experimental Social Psychology 25:1-65. http://dx. doi.org/10.1016/S0065-2601(08)60281-6

Schwartz, S. H. 1994. Are there universal aspects in the structure and contents of human values? Journal of Social Issues 50 (4):19-45. http://dx.doi.org/10.1111/j.1540-4560.1994.tb01196.x

Schwartz, S. H. 1996. Value priorities and behavior: applying a theory of integrated values systems. Pages 1-24 in C. Seligman, J. M. Olsen, and M. P. Zanna, editors. The psychology of values: the Ontario Symposium. Volume 8. Lawrence-Erlbaum, Hillsdale, New Jersey, USA.

Schwartz, S. H. 2012. An overview of the Schwartz Theory of Basic Values. Online Readings in Psychology and Culture 2(1). http://dx.doi.org/10.9707/2307-0919.1116

Selinske, M. J., J. Coetzee, K. Purnell, and A. T. Knight. 2015. Understanding the motivations, satisfaction, and retention of landowners in private land conservation programs. Conservation Letters 8(4):282-289. http://dx.doi.org/10.1111/conl.12154

Shaw, J., D. Hazel, R. Bardon, and K. S. U. Jayaratne. 2012. Landowners' knowledge, attitudes, and aspirations towards woody biomass markets in North Carolina. Journal of Extension 50(4). http://www.joe.org/joe/2012august/pdf/JOE v50 4a9.pdf

Shen, J., and T. Saijo. 2008. Reexamining the relations between socio-demographic characteristics and individual environmental concern: evidence from Shanghai data. Journal of Environmental Psychology 28(1):42-50. http://dx.doi.org/10.1016/j.jenvp.2007.10.003

Slimak, M. W., and T. Dietz. 2006. Personal values, beliefs, and ecological risk perception. Risk Analysis 26(6):1689-1705. http:// dx.doi.org/10.1111/j.1539-6924.2006.00832.x

Sorice, M. G., J. R. Conner, U. P. Kreuter, and R. N. Wilkins. 2012. Centrality of the ranching lifestyle and attitudes toward a voluntary incentive program to protect endangered species. Rangeland Ecology and Management 65(2):144-152. http://dx.doi. org/10.2111/rem-d-10-00144.1

Sorice, M. G., C.-O. Oh, T. Gartner, M. Snieckus, R. Johnson, and C. J. Donlan. 2013. Increasing participation in incentive programs for biodiversity conservation. Ecological Applications 23(5):1146-1155. http://dx.doi.org/10.1890/12-1878.1

Stapp, W., D. Bennet, W. Bryan, J. Fulton, J. MacGregor, P. Nowak, J. Swan, R. Wall, and S. Havlick. 1969. The concept of environmental education. Journal of Environmental Education 1 (1):30-31.

Stern, P. C., L. Kalof, T. Dietz, and G. A. Guagnano. 1995. Values, beliefs, and proenvironmental action: attitude formation toward emergent attitude objects. Journal of Applied Social Psychology 25:1611-1636. http://dx.doi.org/10.1111/j.1559-1816.1995.tb02636. $\underline{x}$

Stern, P. C., T. Dietz, T. Abel, G. A. Guagnano, and L. Kalof. 1999. A value-belief-norm theory of support for social movements: the case of environmentalism. Human Ecology Review 6:81-97.

Uliczka, H., P. Angelstam, G. Jansson, and A. Bro. 2004. Nonindustrial private forest owners' knowledqe of and attitudes towards nature conservation. Scandinavian Journal of Forest Research 19(3):274-288. http://dx.doi.org/10.1080/02827580410029318

United Nations Environment Programme (UNEP). 2010. Decision adopted by the Conference of the Parties to the Convention on Biological Diversity at its Tenth Meeting, 18-29 October. UNEP, Nagoya, Japan. https://www.cbd.int/doc/decisions/ cop-10/full/cop-10-dec-en.pdf

Urquhart, J., P. Courtney, and B. Slee. 2012. Private woodland owners' perspectives on multifunctionality in English woodlands. Journal of Rural Studies 28(1):95-106. http://dx.doi.org/10.1016/ j.jrurstud.2011.08.006

Van Liere, K. D., and R. E. Dunlap. 1978. Moral norms and environmental behavior: an application of Schwartz's norm activation model to yard burning. Journal of Applied Social Psychology 8:174-188. http://dx.doi.org/10.1111/j.1559-1816.1978. tb00775.x

Vining, J., and A. Ebreo. 1992. Predicting recycling behavior from global and specific environmental attitudes and changes in recycling opportunities. Journal of Applied Social Psychology 22:1580-1607. http://dx.doi.org/10.1111/j.1559-1816.1992.tb01758. $\underline{x}$

Warriner, K., J. Goyder, H. Gjertsen, P. Hohner, and K. McSpurren. 1996. Charities, no; lotteries, no; cash, yes: main effects and interactions in a Canadian incentives experiment. Public Opinion Quarterly 60(4):542-562. http://dx.doi.org/10.1086/297772 
Winter, S. J., H. Prozesky, and K. J. Esler. 2007. A case study of landholder attitudes and behavior toward the conservation of Renosterveld, a critically endangered vegetation type in Cape Floral Kingdom, South Africa. Environmental Management 40:46-61. http://dx.doi.org/10.1007/s00267-006-0086-0

Xiao, C., and R. E. Dunlap. 2007. Validating a comprehensive model of environmental concern cross-nationally: a U.S.Canadian comparison. Social Science Quarterly 88(2):471-493. http://dx.doi.org/10.1111/j.1540-6237.2007.00467.x 


\section{Appendix 1}

Short forms of the questions utilized in this study.

\section{Basic Value Dimensions}

15 item short form of Schwartz Value Scale (Stern et al. 1995), 15 items scored.

Self-transcendence (combined biospheric/altruistic, $\alpha=0.87$ ), 6 items scored. How important or unimportant do you feel it is to achieve each of the following goals?

\begin{tabular}{|l|l|l|l|l|l|}
\hline & $\begin{array}{c}\text { Very } \\
\text { Important }\end{array}$ & $\begin{array}{c}\text { Somewhat } \\
\text { Important }\end{array}$ & $\begin{array}{c}\text { Neither } \\
\text { Important or } \\
\text { Unimportant }\end{array}$ & $\begin{array}{c}\text { Somewhat } \\
\text { Unimportant }\end{array}$ & $\begin{array}{c}\text { Very } \\
\text { Unimportant }\end{array}$ \\
\hline $\begin{array}{l}\text { Protecting the environment \& preserving } \\
\text { nature (biospheric) }\end{array}$ & & & & & \\
\hline Being in unity with nature (biospheric) & & & & & \\
\hline $\begin{array}{l}\text { Achieving harmony with the Earth \& other } \\
\text { species (biospheric) }\end{array}$ & & & & & \\
\hline $\begin{array}{l}\text { A world of peace free of war and conflict } \\
\text { (altruistic) }\end{array}$ & & & & & \\
\hline Social justice \& care of the weak (altruistic) & & & & & \\
\hline $\begin{array}{l}\text { Equality \& equal opportunity for all } \\
\text { (altruistic) }\end{array}$ & & & & & \\
\hline
\end{tabular}

Traditionalism ( $\alpha=0.79), 3$ items scored.

How important or unimportant do you feel it is to achieve each of the following goals?

\begin{tabular}{|l|c|c|c|c|c|}
\hline & $\begin{array}{c}\text { Very } \\
\text { Important }\end{array}$ & $\begin{array}{c}\text { Somewhat } \\
\text { Important }\end{array}$ & $\begin{array}{c}\text { Neither } \\
\text { Important or } \\
\text { Unimportant }\end{array}$ & $\begin{array}{c}\text { Somewhat } \\
\text { Unimportant }\end{array}$ & $\begin{array}{c}\text { Very } \\
\text { Unimportant }\end{array}$ \\
\hline Showing respect \& honouring elders & & & & & \\
\hline Family security \& the safety of loved ones & & & & & \\
\hline Having self-discipline \& resisting temptation & & & & & \\
\hline
\end{tabular}

Self-enhancement $(\alpha=0.61), 3$ items scored.

How important or unimportant do you feel it is to achieve each of the following goals?

\begin{tabular}{|l|c|c|c|c|c|}
\hline & $\begin{array}{c}\text { Very } \\
\text { Important }\end{array}$ & $\begin{array}{c}\text { Somewhat } \\
\text { Important }\end{array}$ & $\begin{array}{c}\text { Neither } \\
\text { Important or } \\
\text { Unimportant }\end{array}$ & $\begin{array}{c}\text { Somewhat } \\
\text { Unimportant }\end{array}$ & $\begin{array}{c}\text { Very } \\
\text { Unimportant }\end{array}$ \\
\hline Being a leader or respected authority & & & & & \\
\hline Having an impact on people \&/or events & & & & & \\
\hline Acquiring wealth \& material possessions & & & & & \\
\hline
\end{tabular}

Openness-to-change ( $\alpha=0.69), 3$ items scored.

How important or unimportant do you feel it is to achieve each of the following goals?

\begin{tabular}{|l|c|c|c|c|c|}
\hline & $\begin{array}{c}\text { Very } \\
\text { Important }\end{array}$ & $\begin{array}{c}\text { Somewhat } \\
\text { Important }\end{array}$ & $\begin{array}{c}\text { Neither } \\
\text { Important or } \\
\text { Unimportant }\end{array}$ & $\begin{array}{c}\text { Somewhat } \\
\text { Unimportant }\end{array}$ & $\begin{array}{c}\text { Very } \\
\text { Unimportant }\end{array}$ \\
\hline A varied life full of novelty \& change & & & & & \\
\hline $\begin{array}{l}\text { Achieving an exciting life full of stimulating } \\
\text { experiences }\end{array}$ & & & & & \\
\hline Pursuing curiosity \& being explorative & & & & & \\
\hline
\end{tabular}




\section{Worldviews}

\section{4 items scored.}

New Ecological Paradigm (NEP, $\alpha=0.76$ ), 10 items scored.

Please indicate if you agree or disagree with each of the following statements:

\begin{tabular}{|c|c|c|c|c|c|}
\hline & $\begin{array}{c}\text { Strongly } \\
\text { Agree }\end{array}$ & Agree & $\begin{array}{l}\text { Neither } \\
\text { Agree or } \\
\text { Disagree }\end{array}$ & Disagree & $\begin{array}{l}\text { Strongly } \\
\text { Disagree }\end{array}$ \\
\hline $\begin{array}{l}\text { The balance of nature is very delicate and easily } \\
\text { upset. }\end{array}$ & & & & & \\
\hline $\begin{array}{l}\text { When humans interfere with nature it often } \\
\text { produces disastrous consequences. }\end{array}$ & & & & & \\
\hline $\begin{array}{l}\text { Humans have an ethical obligation to protect } \\
\text { the environment. }\end{array}$ & & & & & \\
\hline $\begin{array}{l}\text { We are approaching the limit of the number of } \\
\text { people Earth can support. }\end{array}$ & & & & & \\
\hline $\begin{array}{l}\text { There are limits to growth beyond which our } \\
\text { industrialized society cannot expand. }\end{array}$ & & & & & \\
\hline $\begin{array}{l}\text { Protecting the environment is so important that } \\
\text { requirements and standards cannot be too high } \\
\text { and continuing environmental improvements } \\
\text { must be made regardless of cost. }\end{array}$ & & & & & \\
\hline $\begin{array}{l}\text { Humans have the right to modify the natural } \\
\text { environment to suit their own needs. }\end{array}$ & & & & & \\
\hline $\begin{array}{l}\text { Mankind was created to rule over the rest of } \\
\text { nature. }\end{array}$ & & & & & \\
\hline $\begin{array}{l}\text { Plants and animals exist primarily to be used by } \\
\text { humans. }\end{array}$ & & & & & \\
\hline $\begin{array}{l}\text { Humans need not adapt to the environment } \\
\text { because they can make it to suit their needs. }\end{array}$ & & & & & \\
\hline
\end{tabular}


Connectedness-to-nature (CNS, $\alpha=0.86$ ), 14 items scored.

Please indicate if you agree or disagree with each of the following statements:

\begin{tabular}{|c|c|c|c|c|c|}
\hline & $\begin{array}{l}\text { Strongly } \\
\text { Agree }\end{array}$ & Agree & $\begin{array}{l}\text { Neither } \\
\text { Agree or } \\
\text { Disagree }\end{array}$ & Disagree & $\begin{array}{l}\text { Strongly } \\
\text { Disagree }\end{array}$ \\
\hline $\begin{array}{l}\text { I often feel a sense of oneness with the natural } \\
\text { world around me. }\end{array}$ & & & & & \\
\hline $\begin{array}{l}\text { I think of the natural world as a community to } \\
\text { which I belong. }\end{array}$ & & & & & \\
\hline $\begin{array}{l}\text { I recognize and appreciate the intelligence of } \\
\text { other living organisms. }\end{array}$ & & & & & \\
\hline I often feel disconnected from nature. & & & & & \\
\hline $\begin{array}{l}\text { When I think of my life, I imagine myself to be } \\
\text { part of a larger cyclical process of living. }\end{array}$ & & & & & \\
\hline I often feel a kinship with animals and plants. & & & & & \\
\hline $\begin{array}{l}\text { I feel as though I belong to the Earth as equally } \\
\text { as it belongs to me. }\end{array}$ & & & & & \\
\hline $\begin{array}{l}\text { I have a deep understanding of how my actions } \\
\text { affect the natural world. }\end{array}$ & & & & & \\
\hline I often feel part of the web of life. & & & & & \\
\hline $\begin{array}{l}\text { I feel that all inhabitants of Earth, human, and } \\
\text { nonhuman, share a common 'life force'. }\end{array}$ & & & & & \\
\hline $\begin{array}{l}\text { Like a tree can be part of a forest, I feel } \\
\text { embedded within the broader natural world. }\end{array}$ & & & & & \\
\hline $\begin{array}{l}\text { When I think of my place on Earth, I consider } \\
\text { myself to be a top member of a hierarchy that } \\
\text { exists in nature. }\end{array}$ & & & & & \\
\hline $\begin{array}{l}\text { I often feel like I am only a small part of the } \\
\text { natural world around me, and that I am no more } \\
\text { important than the grass on the ground or the } \\
\text { birds in the trees. }\end{array}$ & & & & & \\
\hline $\begin{array}{l}\text { My personal welfare is independent of the } \\
\text { welfare of the natural world. }\end{array}$ & & & & & \\
\hline
\end{tabular}




\section{Norm Activation Theory 13 items scored.}

Awareness-of-consequences (AC, $\alpha=0.91), 8$ items scored.

To what extent do you feel the following environmental issues are serious or not serious problems in Ontario?

\begin{tabular}{|l|l|l|l|l|l|}
\hline & $\begin{array}{c}\text { Definitely not } \\
\text { a Problem }\end{array}$ & $\begin{array}{c}\text { Probably not } \\
\text { a Problem }\end{array}$ & $\begin{array}{c}\text { Slight } \\
\text { Problem }\end{array}$ & $\begin{array}{c}\text { Serious } \\
\text { Problem }\end{array}$ & $\begin{array}{c}\text { Unsure/Don't } \\
\text { Know }\end{array}$ \\
\hline Damage to plants \& animal species & & & & & \\
\hline Loss of plants \& animal species & & & & & \\
\hline Threats to endangered species & & & & & \\
\hline Loss of quality woodlands & & & & & \\
\hline Loss of greenspace & & & & & \\
\hline Spread of invasive species & & & & & \\
\hline Threats to water quality & & & & & \\
\hline Climate change & & & & & \\
\hline
\end{tabular}

Personal Norm (PN, $\alpha=0.70$ ), 5 items scored.

Please indicate if you agree or disagree with each of the following statements:

\begin{tabular}{|l|l|l|l|l|}
\hline & $\begin{array}{c}\text { Strongly } \\
\text { Agree }\end{array}$ & Agree & $\begin{array}{c}\text { Neither } \\
\text { Agree or } \\
\text { Disagree }\end{array}$ & $\begin{array}{c}\text { Disagree } \\
\text { Strongly } \\
\text { Disagree }\end{array}$ \\
\hline $\begin{array}{l}\text { I feel a strong personal obligation towards } \\
\text { preserving the environmental features of this } \\
\text { property. }\end{array}$ & & & & \\
\hline $\begin{array}{l}\text { Working to maintain the environmental } \\
\text { features of this property is not always worth it. }\end{array}$ & & & & \\
\hline $\begin{array}{l}\text { To me maintaining the environmental features } \\
\text { of this property is largely a matter of money; } \\
\text { wouldn't do it unless there was a financial } \\
\text { reward. }\end{array}$ & & & & \\
\hline $\begin{array}{l}\text { I would preserve the environmental features of } \\
\text { this property in exactly the same way with or } \\
\text { without government incentives. }\end{array}$ & & & & \\
\hline $\begin{array}{l}\text { I would fee guilty if we didn't succed in } \\
\text { preserving and environmental features of this } \\
\text { property. }\end{array}$ & & & & \\
\hline
\end{tabular}




\section{Theory of Reasoned Action}

Attitude-toward-the-act (AA, $\alpha=0.96), 9$ items scored.

In relation to the following environmental goals how effective or ineffective do you feel the CLTIP as been?

\begin{tabular}{|l|l|l|l|l|l|}
\hline & $\begin{array}{c}\text { Very } \\
\text { Effective }\end{array}$ & $\begin{array}{c}\text { Somewhat } \\
\text { Effective }\end{array}$ & $\begin{array}{c}\text { Somewhat } \\
\text { Ineffective }\end{array}$ & $\begin{array}{c}\text { Very } \\
\text { Ineffective } \\
\text { Know/Cannot } \\
\text { Say }\end{array}$ \\
\hline $\begin{array}{l}\text { Protecting natural heritage \& } \\
\text { biodiversity }\end{array}$ & & & & & \\
\hline $\begin{array}{l}\text { Helping to preserve representative } \\
\text { ecosystems }\end{array}$ & & & & & \\
\hline Protecting endangered species & & & & & \\
\hline Maintaining habitat & & & & & \\
\hline Preserving woodlands & & & & & \\
\hline Encouraging woodland management & & & & & \\
\hline $\begin{array}{l}\text { Preventing incompatible uses of } \\
\text { greenspace }\end{array}$ & & & & & \\
\hline $\begin{array}{l}\text { Promoting natural heritage } \\
\text { conservation }\end{array}$ & & & & & \\
\hline Protecting water quality & & & & \\
\hline
\end{tabular}




\section{Landowner socio-demographic landowner characteristics}

Conservation program participation

Which of the following best describes your involvement in the CLTIP or MFTIP?

- Participant in the CLTIP

- Participant in the MFTIP

- Formerly participant in the CLTIP or MFTIP

- Never a participant in either the CLTIP or MFTIP

Gender

What is your gender?

$\square$ Male $\square$ Female

\section{Education}

What is your educational background?

- Some grade school or high school

- High school diploma

- Some college or technical school

- College or technical school diploma

- Some university

- University bachelor's degree (e.g., BA, BSc, BEd, etc.)

- University professional degree (e.g., MD, LLB, MBA, etc.)

- University graduate degree (e.g., MA, MSc., PhD, etc.)

\section{Household Income}

What is the approximate total income for this household? Please include income received by all members of the household from all sources including wages and salaries, business earnings, investments, pensions and/or government transfers.

- less than $\$ 19,999$

- $\$ 20,000$ - $\$ 39,999$

- $\$ 40,000-\$ 59,999$

- $\$ 60,000$ - $\$ 79,999$

- $\$ 80,000$ - $\$ 99,999$

- $\$ 100,000-\$ 119,999$

- $\$ 120,000$ - $\$ 139,999$

- $\$ 140,000$ - $\$ 159,999$

- $\$ 160,000$ - $\$ 179,999$

- $\$ 180,00$ or more 
Political Leaning

We often hear of the distinction between people who consider themselves to be "right leaning" in terms of the political spectrum and those who consider themselves "left leaning." Please indicate the degree to which you consider yourself to be either generally "right" or "left" in terms of your political views.

\begin{tabular}{|c|l|c|c|c|c|c|}
\hline Extremely Left & Left & $\begin{array}{c}\text { Moderately } \\
\text { Left }\end{array}$ & Neither & $\begin{array}{c}\text { Moderately } \\
\text { Right }\end{array}$ & Right & $\begin{array}{c}\text { Extremely } \\
\text { Right }\end{array}$ \\
\hline
\end{tabular}

\section{Eligible Property Area}

What is the area of land on this property qualifying for either the CLTIP or MFTIP? 


\section{Appendix 2}

Numbers of participating (P) and non-participating (N-P) CLTIP eligible landowners by program eligible acreage, as well as sample sizes for proportional and disproportional sampling.

\begin{tabular}{llcccccc}
\hline & & & \multicolumn{2}{c}{$\begin{array}{c}\text { Proportionate } \\
\text { sampling }\end{array}$} & \multicolumn{2}{c}{$\begin{array}{c}\text { Disproportionate } \\
\text { sampling }\end{array}$} \\
\hline Group & Acreage (ha) & $\mathrm{N}$ & \% by strata & $\mathrm{n}$ & $\%$ & $\mathrm{n}$ & $\%$ \\
\hline $\mathrm{P}$ & $0.2-2.0$ & 6,873 & 13 & 104 & 13 & 130 & 16.25 \\
& $2.01-4.0$ & 3,275 & 6 & 48 & 6 & 60 & 7.5 \\
& $4.01-12.0$ & 5,647 & 11 & 88 & 11 & 110 & 13.75 \\
& $>12$ & 5,577 & 10 & 80 & 10 & 100 & 12.5 \\
& Total & 21,372 & 40 & 320 & 40 & 400 & 50 \\
\hline N-P & $0.2-2.0$ & 12,687 & 23 & 184 & 23 & 154 & 19.25 \\
& $2.01-4.0$ & 5,393 & 10 & 80 & 10 & 66 & 8.25 \\
& $4.01-12.0$ & 8,621 & 16 & 128 & 16 & 106 & 13.25 \\
& $>12$ & 5,661 & 11 & 88 & 11 & 74 & 9.25 \\
& Total & 32,362 & 60 & 480 & 60 & 400 & 50 \\
\hline & Total & 53,734 & 100 & 800 & 100 & 800 & 100 \\
\hline
\end{tabular}

